\title{
Politik Halkla İlișkilerde Sosyal Medya Kullanımı: 30 Mart 2014 Yerel Seçimleri ve 10 Ağustos 2014 Cumhurbașkanlığı Seçimleri
}

\author{
Ferah Onat ${ }^{1}$ \\ Cudi Kaan Okmeydan ${ }^{2}$
}

\begin{abstract}
Öz
Günümüzde, siyasal yaşamda birçok siyasi örgüt ve siyasi karakterin sosyal medya platformları üzerinden hedef kitlelerine ulaşmaya çalıştıkları görülmektedir. Politik halkla ilişkiler aracı olarak sosyal medya ilk kez 2008 ABD Başkanlık seçimlerinde, ardından 2010'da Avustralya ve Birleşik Krallık Genel Seçimleri'nde kullanılmıştır. Türkiye'de siyasal partilerin ve adayların sosyal medyaya olan ilgileri Türk halkının yeni iletişim teknolojilerine olan odaklanmasıyla paralel olarak günden güne artmaktadır. Bu araştırmanın amacı Türk adayların sosyal medyadaki uygulamalarının Grunig ve Hunt'ın iletişim teknolojilerinin yaygın kullanımıyla daha çok gündeme gelen çift yönlü asimetrik model ya da çift yönlü simetrik modellerinden hangisiyle daha çok örtüştüğünü ortaya çıkarmaktır. Araştırma Türkiye 30 Mart 2014 Yerel Seçimleri dönemi ve 10 Ağustos 2014 Cumhurbaşkanlığı Seçimi dönemi olmak üzere iki ayrı seçim dönemini kapsamaktadır. Araştırma kapsamında yerel seçimlere katılan üç büyük ildeki, üç büyük partinin belediye başkanı adayları ve üç cumhurbaşkanı adayının resmi Facebook ve Twitter hesapları incelenmiştir. Hesaplarda paylaşılan gönderiler ve etkileşim durumu niceliksel içerik analizi uygulanarak çözümlenmiştir. Bunun yanında bir adayın seçim döneminde sosyal medya hesaplarını yöneten sosyal medya uzmanlarıyla derinlemesine mülakat yapılmıştır.
\end{abstract}

Anahtar kelimeler: Siyasal İletişim, Halkla İlişkiler, Political Halkla Illişkiler, Sosyal Medya

\begin{abstract}
Today, it is observed that many political organizations and figures are trying to reach their target publics via social media platforms. Social media, a political public relations tool, was intensively used in $\mathbf{2 0 0 8}$ for the first time in presidential elections of the USA, followed by Australia and the United Kingdom General Elections held in 2010. In Turkey, the interest of political parties and candidates towards social media has been increasing day by day in parallel with the focus of Turkish people on new communication technologies. The aim of this research is to find out which of four public relations model of the Grunig and Hunt's matched with the social media practices of Turkish candidates, the ones that are frequently used with the emergence of communication technologies. This research comprises two different election periods in Turkey; Local Elections held in March, 30, 2014 and Presidential Elections held in August, 10, 2014. Within the scope of the research, official Facebook and Twitter accounts of Mayor candidates of three metropolitans from the first three popular parties and also three presidential candidates are analysed. All of the posts and interactions are analysed by using quantitative content analysis. Furthermore, interviews are made with the social media experts of one of the candidates who had run the candidate's social media accounts during the election period.
\end{abstract}

Keywords: Political Communication, Public Relations, Political Public Relations, Social Media

1 Doç.Dr., Yaşar Üniversitesi

2 Arş. Gör., Yaşar Üniversitesi 


\section{Giriș}

$\mathrm{H}$ alkların kendi yöneticilerini seçtiği demokratik ülkelerde siyasal bir rekabet söz konusudur. Bu tip demokratik ve çok partili düzenlerde her parti ve siyasetçi kendisini tercih ettirmek adına seçmen hedef kitlesini ikna etmek durumundadır. Bu ikna faaliyetleri miting, konferans, toplantı ve ziyaret gibi siyasal aktörle seçmen kitlenin aynı ortamda bulunduğu aracısız iletişim yöntemlerinin yanı sıra, daha geniş kitlelere ulaşmak adına afiş, el ilanı, gazete, radyo, televizyon gibi geleneksel medya ortamları vasıtasıyla da gerçekleşebilmektedir. Ancak günümüz politik halkla ilişkiler faaliyetlerinde sadece tek yönlü mesaj iletebilen geleneksel medya platformları yetersiz kalmaya başlamıştır.

Günümüzde yeni medya olarak da adlandırılan sosyal medya ortamları geleneksel medyanın aksine karşılıkı iletişim ortamı sağlamakta ve anında geribildirim alınmasına imkan vermektedir. $\mathrm{Bu}$ açıdan bakıldığında sosyal medya, siyasal aktör ve siyasi parti için hedef kitlesiyle karşılıklı ve kesintisiz iletişim ortamı sağlayan ve geri bildirimin anında alınmasına imkan veren interaktif bir ortamdır.

Sosyal medya üzerinden yürütülen ilk etkin politik halkla ilişkiler faaliyetine 2008 ABD Başkanlık seçimleri örnek gösterilmektedir. Sözkonusu dönemde Demokratik Parti Adayı, Barack Obama toplam 16 farklı sosyal medya ortamı üzerinden seçmenleriyle iletişim kurmaya çalışmıştır. ABD Başkanlık Seçimleri'nin ardından 2010 yılında Birleşik Krallık ve Avusturalya'da gerçekleşen seçimlerde de partilerin ve adayların sosyal medyaya yöneldikleri görülmüştür.

Türkiye'de ise siyasal amaçlı internet kullanımı ilk kez 2002 Genel Seçimleri döneminde görülmüştür. Söz konusu dönemdeinternet teknolojilerinin sunduğu sınırlı olanaklar çerçevesinde partiler, kendi Web sitelerini düzenlemişler ve internetteki bazı haber portallarına reklam vermişlerdir. 2007 Genel Seçimleri'nde ise bu süreç biraz daha gelişmiştir. Bu dönemde partilerin Web sayfaları işlevselleşmiş, bazı partilerin kendi adlarına forum siteleri açtıkları ve adayların kendi adlarına Facebook ve Twitter başta olmak üzere sosyal medya ortamlarında hesaplar oluşturdukları görülmüştür. Bunun yanı sıra 12 Haziran 2011 Genel Seçimlerinde tüm partilerin ve adayların en az bir sosyal medyada aktif olmaya çalıştıkları görülmüştür. Ancak her şeye rağmen, Türkiye'de siyasi partilerin halkla ilişkiler çalışmalarında sosyal medya kullanımına yönelik olarak gerçekleştirilen çalışmaların yeterli olmadığı söylenebilir.

Bu çalışmada, Türkiye'deki siyasi adayların politik halkla ilişkiler çalışmalarında sosyal medyanın yerini belirlemek ve sosyal medya üzerinden yürütülen halkla ilişkiler çalışmalarında Grunig ve Hunt'ın çift yönlü halkla ilişkiler modellerinden hangisinin öne çıktığını saptamak amaçlanmaktadır. Çalışmanın literatüründe kavramların daha iyi anlaşılabilmesi adına siyasal iletişim, politik halkla ilişkiler, halkla ilişkiler modelleri ve sosyal medya olgusuna ayrıntılı bir şekilde yer verilmiştir. Araştırma bölümünde ise 30 Mart 2014 yerel seçimleri ve 10 Ağustos 2014 cumhurbaşkanlığı seçimlerine katılan adayların sosyal medya kullanımları incelenmiştir. Araştırmanın ilk sorusu adayların sosyal medya ortamları üzerinden hedef kitleleri ile kurdukları iletişimin Grunig ve Hunt'ın dört halkla ilişkiler modeli arasında yer alan çift yönlü modellerden hangisiyle örtüştüğü yönündedir. Ortaya çıkan bulgular adayların sosyal medya hesapları üzerinden takipçileri ile kurdukları iletişimin Grunig ve Hunt'ın çift yönlü asimetrik modeliyle örtüştüğünü göstermektedir. Araşıımanın ikinci sorusu ise adayların sosyal medya ortamlarındaki hesapları üzerinden biçimsel olarak ne tür paylaşımlarda bulundukları yönündedir. Ortaya çıkan bulgular paylaşımların biçimsel olarak çoğunlukla fotoğraf ve metin paylaşımlarından oluştuğunu göstermiştir. 


\section{Siyasal İletișim Olgusu}

Siyasal iletişim insanlar insanlar arasında yöneten ve yönetilen ilişkisinin varolmasından bu yana sözkonusudur. Toplu halde yaşayan kitleyi yönetebilme çabası siyasetin asıl varlık nedenidir (Kılıçaslan, 2008). Ancak siyasetin amacına ulaşabilmesi ve başarılı olabilmesindeki ön koşul kitlelerin ikna edilmesi ve rızalarının alınmasıdır. Özellikle demokratik ülkelerde siyasal gücün seçimle kazanılıp seçimle kaybedilmesi siyasette hedef kitle memnuniyetinin önemine işaret etmektedir (Polat vd.,, 2004: 3). Demokrasi ile yönetilen toplumlarda yönetim sorumluluğunu alan veya bu sorumluluğa talip olan siyasi aktör veya partilerinhedeflerine ulaşabilmek için halk ile siyasal etkileşim içinde kalma zorunlulukları bulunmaktadır (Karaçor, 2009: 123). Bu bağlamda seçmen kitlenin memnuniyetinin sağlanması, ikna edilmesive sözkonusu kitle ile yaşanan iletişimsel süreç siyasal iletişimin ilgi alanına işaret etmektedir.

Aziz (2011: 3), siyasal iletişimi en basit şekilde "Siyasal aktörlerin belli ideolojik amaçlarını, belli gruplara, kitlelere, ülkelere ya da bloklara kabul ettirmek ve gerektiğinde eyleme dönüştürmek, uygulamaya koymak üzere çeşitli iletişim tür ve tekniklerini kullanmaları" olarak tanımlamaktadır. Daha genel ve sade bir tanımla siyasal iletişim; iktidar olabilmek için kamuoyu desteği ve güvenini sağlamak adına zamanın gereklerine göre reklam, propaganda ve halkla ilişkiler taktiklerinden yararlanarak sürekli olarak gerçekleştirilen tek veya çift yönlü iletişimi ifade etmektedir (Özkan 2004'den aktaran, Yolçu, 2011: 3). Tüm bu tanımlardan yola çıkarak siyasi aktör veya siyasi partinin amaçlarına ulaşabilmek adına reklam, propaganda, halkla ilişkiler gibi farklı taktiklerden ve kitle iletişim araçlarından yararlanarak seçmen kitle ile iletişim kurma çabalarının siyasal iletişimi tanımladığı görülmektedir.

\section{Politik Halkla İlișkiler Olgusu}

Politik halkla ilişkiler, Strömback ve Kiousis (2011: 308)'a göre politik amaçları olan, bir bireyin ya da örgütün misyonuna destek almak ve hedeflerine ulaşmak için kendisine anahtar olacak hedef grupları etkilemeye, onlarla faydalı ilişkiler kurmaya ve sürdürmeye ihtiyaç duyan ve bu amaçla iletişim ve eylem yapan bir yönetim sürecidir. Kamusal alandaki geniş kitlelere gönderilen mesajlar da politik halkla ilişkiler olgu ve süreci içerisinde çalışmaktadır. Kamu yönetiminde halkla ilişkiler uygulamalarının iki temel amacı vardır. Birincisi yönetimle ilgili olarak kamudaki güven duygusunu artırmak ikincisi ise oluşabilecek bir takım sorunları engellemek ve mevcut sorunların krize dönüşmesinin önüne geçmektir (Aziz, 2011: 14).

Mahmut Oktay, politik halkla ilişkileri; "iktidar, siyasi örgüt ya da siyasal aktör ile halk arasında karşılıklı münasebet geliştirip koruyan, örgütün ya da siyasetçinin politikalarını kamuoyu çıkarlarıyla örtüştüren ve kamuoyu tarafından örgüte veya siyasetçiye karşı güven ve sempati duygularının gelişmesini sağlayan bir halkla ilişkiler türü" olarak tanımlanmaktadır (Oktay, 2002: 76). Tek başına reklam kampanyalarının ve reklamın siyasette güven oluşturma açısından son derece yetersiz kalması siyasette de halkla ilişkilerin önemini giderek arttırmaktadır. Reklamın aksine halkla ilişkiler yönetiminde iletişim kontrolü politikacının kendisinde ya da iletişim danışmanlarında değil medyadadır (Barut ve Altundağ, 2005). Medya kuruluşu politikacının ya da partisinin basın toplantılarını, demeçlerini, açıklamalarını, davetlerini ve benzeri etkinliklerini yayın kapsamına alıp almama ve istediği yer, kapsam ve yorumla yayınlama özgürlüğüne sahiptir. Halkla ilişkiler yönteminde ise mesaj bir haber muamelesi görmekte ve haber değeri ölçüsünde değerlendirilmektedir. Bu durumun mesajı veren taraf için avantajı ise yayın yönteminin reklamda olduğu gibi paralı değil bedava olmasıdır. Ayrıca yayın kontrolünün mesajı veren taraf yerine medyada olması onun reklamdan daha objektif, güvenilir ve tarafsız olduğu izlenimini doğurmaktadır. Siyasal reklam yerine politik halkla ilişkiler uygulamaları hem maliyet hem de 
güvenilirlik yönünden daha çok tercih edilmesi gereken bir siyasal iletişim yöntemidir (Oktay, 2002: 76).

\section{Halkla İlișkiler Modelleri ve Çift Yönlü İletișimin Önemi}

Örgüt ve kuruluşların çevreleri ile kurdukları iletişime açıklık getirmeyi amaçlayan sistem kuramı açık ve kapalı sistem olmak üzere iki kategoriden oluşmaktadır. Açık sistemde kuruluşlar iç ve dış hedef kitleleri ile bilgi alışverişi ve iletişim içindedirler. Ancak kapalı sistemde kuruluşlar çevreleri ile bilgi alışverişinde bulunmaktan ve iletişim kurmaktan kaçınmaktadırlar. Halkla ilişkilere sistem kuramı penceresinden bakıldığında ortaya açık sistem çıkmaktadır. Hedef kitlesi ile bilgi alışverişinde bulunmayan ve iletişim kurmayan kurum ve kuruluşlarda halkla ilişkilerden söz edilemez. Ayrıca halkla ilişkiler için hayati önem taşıyan geri bildirim yine açık sistemde mümkündür (Hickson ve Hill, 1991'den aktaran Toth, 2008: 74). Grunig ve Hunt'un dört halkla ilişkiler modeli ise sistem kuramının üzerine geliştirilen organizasyon kuramı bakış açısıyla ortaya koyulmuştur. Organizasyon kuramı, kendilerini toplumdan soyutlamaları mümkün olmayan kuruluşların, başarıı olabilmeleri için hedef gruplarıyla mutlaka iletişim içinde olmaları gerektiğini savunmaktadır (Okay ve Okay, 2007: 108). Hali hazırda halkla ilişkiler uygulamalarındaki iletişim süreçlerinin özelliğini iletişimin doğasına göre belirleyen sınırlı sayıda halkla ilişkiler modelleri bulunmaktadır. Grunig ve Hunt'ın 4 halkla ilişkiler modeli en yaygın ve en genel olarak kullanılan modellerdir. Bu nedenle sosyal medya ve halkla ilişkilere dair pek çok kaynakta aynı modeller üzerinden uygulamalar değerlendirilmektedir.

Grunig ve Hunt'ın geliştirdiği dört temel halkla ilişkiler modeli tarihsel sentez niteliğini taşımaktadır. Modeller sırasıyla; Basın ajansı/tanıtım, Kamuyu bilgilendirme, İki yönlü asimetrik ve iki yönlü simetrik modelden oluşmaktadır. İlk iki model halkla ilişkilerde geleneksel medya ilişkilerini hedefler ve tek yönlü iletişime dayalıdır. Son iki model de ise bilimsel ikna ve ilişki geliştirmeye dayalı halkla ilişkiler anlayışı söz konusudur (Wilcox ve Cameron, 2011: 53).

Basın ajansı modeli propagandaya yönelik bir yaklaşım üzerine kurulmuştur. Tek yönlü iletişimin söz konusu olduğu bu modelde asıl amaç her ne şekilde olursa olsun medyanın ilgisini çekebilmektir. Kamuoyu bilgilendirme modeli ise gazetecilik mantığı temel alınarak geliştirilmiştir. Bu modelde kurumla ilgili olumlu haberlerin basında duyurulmasu esastır. Kamuyu bilgilendirme modelini, basın ajansı modelinden ayıran en önemli unsur iletilen bilgilerin doğru olmasıdır (Grunig vd., 1995). Son iki model ise daha karmaşık ve gelişmiş bir yapıya sahiptir. İletişim teknolojilerinin getirdiği olanaklar ve sosyal medyanın interaktif ortamı nedeniyle ilk iki modelin artık güncelliğini yitirdiği söylenebilir. Çift yönlü iletişimin esas alındığı modellerde araştırma önemli bir yer tutmaktadır. Çift yönlü asimetrik modelde bilgi dışarıdan içeriye değil içeriden dışarıya doğru akar. Bilimsel ikna çabalarına yöneliktir. Alıcıdan edinilen geribildirim kaynağın daha etkin ikna stratejisi geliştirebilmesi için kullanılmaktadır. Bu modelde kurum muhafazakârdır, davranış ve tutum değişikliğine gitmez ve iletişim daima kurum yararına fayda sağlayacak şekilde tasarlanmıştır (Grunig ve White, 2005: 56). Çift yönlü simetrik modelde ise uzlaşmaya ve diyaloğa dayalı bir strateji söz konusudur. Amaç diyalog ve karşılıklı anlayış geliştirmektedir. Bu modelde kurum alıcıdan edindiği geribildirim doğrultusunda tutum değişikliğine gidebilmektedir. Model hem kurumun hem hedef kitlenin çıkarlarını korumaya yöneliktir (Grunig vd., 1995). Bu modelde örgütlerin kendilerini çevrelerinden tecrit edemeyecekleri ve örgütlerin birbirine nüfuz edeci açık sistemi uyguladıkları varsayılmaktadır (Grunig ve White, 2005: 56). 


\section{Sosyal Medya Kavramı ve İçeriği}

Gelişen internet teknolojileri ile pasif birer izleyici veya okuyucu olan internet kullanıcıları web üzerindeki etkinliklerini artırmışlardır. İnternet kullanııılarının kendi içeriklerini oluşturmaları ve paylaşmaları yani interaktif iletişime dayalı bilginin özgürce dolaşımı 2004 yılında O'Reilly Media'nın kurucusu Tim O'Reilly tarafından Web 2.0 olarak adlandırılmıştır (Kahraman, 2013: 19). Bu bağlamda Web 2.0 olguyu teknolojik boyutuyla sosyal medya ise olguyu daha çok sosyolojik boyutuyla tanımlayan kavramlar olarak karşımıza çıkmaktadır (Akar, 2011: 21).

Sosyal medyayı, Bruns ve Bahnisch, "Geniş anlamda Web 2.0 teknolojileri üzerine kurulan, daha derin sosyal etkileşime, topluluk oluşumuna ve işbirliği projelerini başarmaya imkan sağlayan Web siteleri" olarak tanımlamaktadır (Açıkel ve Çelikol, 2012: 43). Ancak sosyal medyanın, bireylerin hiçbir teknik bilgi gereksinimi olmadan internette oluşturdukları içerikler, paylaşımlar ve birbirleriyle kurdukları diyaloglar sonucunda ortaya çıkan bir kavram olduğu görülmektedir.

Bloglar, mikrobloglar, sosyal ağ siteleri, medya paylaşım siteleri, vikiler, lokasyon bazlı servisler, RSS ve podcast'ler gibi sanal ortamlar günümüzün en yaygın ve bilinen sosyal medya araçları olarak kabul görmektedirler (Akar, 2011: 14). Bu ortamlar bireyler tarafından iletişim, sosyalleşme ve bilgi alma amaçı olarak kullanılmakla birlikte, kurum ve kuruluşlar tarafından da modern bir pazarlama ve halkla ilişkiler aracı olarak görülmektedir.Çünkü sosyal medya doğru zamanda doğru içeriği doğru kitleye ulaştırabilme gücüne sahiptir (Okmeydan, 2013: 54). Bu yönüyle sosyal medya hedef kitlesine ulaşmaya çalışan kurum ve kuruluşlar açısından da gün geçtikçe önem kazanmaktadır.

\section{Politik Halkla İlișkiler Aracı Olarak Sosyal Medya}

Sosyal medya; sosyal ağlar, bloglar, mikro bloglar, video paylaşım siteleri ve forumlar gibi interaktif web sitelerinden oluşmaktadır. Bu ortamlararacııı̆̆ıla siyasi örgüt veya siyasal aktör hiçbir zaman ve mekan sınırlaması olmadan hedef kitlesi ile karşııkı iletişim içinde kalabilmektedir. Ayrıca bu ortamlar anında geribildirim edinilmesine de olanak sağlamaktadır (Hanson, vd, 2010). Bu nedenle sosyal medya siyasi örgüt veya siyasi karaktere halkla ilişkiler çalışmalarında geleneksel medyaya oranla çok daha önemli fırsatlar sunmaktadır. Bu fırsatlar ilk etapta, siyasi karakter ile seçmen kitlenin zaman ve mekan sınırlaması olmadan karşılıklı iletişim kurabilmeleri ve bu bağlamda karşııılı anlayış ve hoşgörü ortamının oluşması, anında geri bildirimin sağlanması ve çok daha düşük iletişim maliyetleri olarak kendisini göstermektedir.

Foot ve Schneider politik halkla ilişkilerde bilgi ve iletişim teknolojilerinin stratejik olarak kullanılmasını dijital çağın bir gerekliliği olarak görmektedir (Foot ve Schneider 2006'dan aktaran Strömback ve Kiousis, 2011:295). Bu noktadan hareketle Tedesco da politik halkla ilişkiler kampanyalarında bilgi ve iletişim teknolojilerinin önemli fırsatlar sunduğunu ve bu ortamlar üzerinden Grunig ve Hunt'un çift yönlü simetrik modelinden başarıyla yararlanılabiliceğini belirtmektedir. Ancak Tedesco'ya göre, dijital ortamlarda yer alınacaksa, dijital araçların diğer tanıtım araçlarıyla nasıl bağlanacağının stratejik bir biçimde planlanması gerekmektedir (Tedesco 2004'den aktaran Strömback ve Kiousis, 2011:295).

Politik halkla ilişkiler amaçı sosyal medya kullanmı ilk kez 2004 ABD Senato seçimlerinde sınırlı olarak kendisini göstermiştir. Bu süreçte adayların blogları ve web sayfaları devreye girerek özel içerikler oluşturulmuştur. İlerliyen yıllarda sosyal ağlar ve video paylaşım siteleri de bu süreçte yer almaya başlamıştır (Strömback ve Kiousis, 2011:294). Ancak politik iletişim çalışmalarında sosyal medya kullanımı ilk kez 2008 ABD Başkanlık Seçimleri döneminde Demokrat Parti Adayı Obama'nın sosyal medya üzerinden yürüttüğü seçim kampanyası ile gündeme gelmiştir. Bu 
dönem; siyasal kampanyalarda Facebook, Myspace ve Youtube çağının başlangıcı olarak kabul edilmiştir (Hanson, vd. 2010). Seçim süresince Facebook, Twitter, MySpace gibi toplam 16 farklı sosyal medya platformunda yeralan Obama, Facebook grubunda 2.2 milyon üyeye ulaşmıştır (Vural ve Bat, 2009). Birleşik Krallık 2010 seçimlerinde de partilerin ve adayların sosyal medyaya olan ilgileri seçimlere damga vurmuştur. Bu süreçte adaylar kendi adlarına bloglar açıp, Facebook ve Twitter'da profil oluşturmuşlardır (Baxter ve Marcella, 2012). Yine 2010 yılında gerçekleşen Avusturalya Genel Seçimleri'de yoğun sosyal medya kullanımına sahne olmuştur. Bu süreçte Yeşiller, Liberal Parti ve Avusturalya İşçi Partisi olmak üzere üç büyük partinin ve liderlerinin sosyal medya platformları aracılığı ile seçmenlerine ulaşmak için çaba sarf ettikleri görülmüştür. Günümüzde dünyanın dört bir yanında siyasal kurumlar ve siyasal aktörler gerçekleştirdikleri iletişim çalışmalarında mutlaka sosyal medya ortamlarından yararlanmaktadırlar. Sosyal medya onlara seçmenle karşııklı iletişim kurma ve seçmen tepkilerini ölçümleme imkanı sağlayan yegane kitle iletişim aracıdır.

\section{Türkiye’de Politik Halkla Illișkiler Çalıșmalarında İnternet ve Sosyal Medya Kullanımı}

Türkiye'deki siyasi partilerinin Web sayfalarını aktif olarak kullanmaları ve internetteki bazı haber portallarına reklam vermeleri ilk kez 2002 Genel Seçimleri döneminde ortaya çıkmıştır. Ancak bu dönemde partiler Web sitelerini sadece geleneksel medya mantığıyla kullanıımıştır. Partilerin sayfaları, seçim beyannamelerini, seçim şarkılarını, Genel Başkan'ın video görüntülerini ve fotoğraflarını içermekte ve Genel Başkan'ın miting programlarıyla ilgili bilgileri iletmekteydi ancak seçmenle iletişim kurmaya yönelik bir e-posta ya da ileti kutucuğu Web sayfalarında yeralmamaktaydı (Alemdar ve Köker, 2011).

2007 Genel Seçimleri'ne gelindiğinde ise siyasi partilerin Web sayfalarının biraz daha işlevsel ve interaktif bir görünüme büründüğü, seçmenlerin soru, sorun, şikayet ve görüşlerini iletebilecekleri bir e-posta kutusu olduğu, internetteki siyasi reklamlarda da artış gözlemlendi. Ancak tam anlamıla internet destekli seçim kampanyası ilk kez 2009 yerel seçimlerinde "www.akparti.gen. tr" adresli bir forum ve "www.tayyip.biz" olmak üzere bir blog açmış ve Türk siyasal yaşamında ilk kez sosyal medya ortamlarından faydalanmıştır. Ayrıca söz konusu sosyal medya hesapları partinin resmi Web sayfasına bağlanarak site ziyaretçilerinin bu hesaplardan haberdar olmaları sağlanmıştır (Sarı, 2010). Yine bu seçim döneminde birçok partinin gençlik kolları parti ve adayları adına sosyal medya ortamlarında hesap açmışlar, bazı belediye başkan adayları da Facebook'ta oluşturdukları sayfalarından halka seslenmişlerdir (Bayraktutan vd. 2012). Bu seçimlerden sonra neredeyse her partinin sosyal medyada aktif olarak yer almaya çalıştığı görülmüştür.

\section{30 Mart 2014 Yerel Seçimleri Adayları Ve 10 Ağustos 2014 Cumhurbașkanlığı Seçimleri Adayları Sosyal Medya Kullanımlarına Yönelik Araștırma}

Bu çalışma, Türkiye'deki siyasi adayların siyasal iletişim ve halkla ilişkiler çalışmalarında sosyal medyanın yerini belirlemeyi ve adayların sosyal medya ortamları üzerinden hedef kitleleriyle kurdukları iletişimin Grunig ve Hunt'unçift yönlü asimetrik ve çift yönlü simetrik olmak üzere çift yönlühalkla ilişkiler modellerinden hangisiyle örtüştüğünü ve paylaşımların biçimsel olarak hangi içeriklerden oluştuğunu ortaya koymayı amaçlamaktadır.

\subsection{Araștırmanin Yöntemi}

Araştırma iki ayrı seçim dönemini kapsamaktadır. İlk olarak 30 Mart 2014 Yerel Seçimleri dönemi, 
ikinci aşamada ise 10 Ağustos 2014 Cumhur Başkanlığı Seçimleri dönemi incelenmiştir. Araştırm da iki yöntem kullanılmıştır. İlk yöntem araştırmaya dahil edilen siyasi adayların resmi sosyal medya hesaplarına yönelik olarak gerçekleştirilen niceliksel içerik analizidir. Bu ortamlar, adayların kendi Web sayfaları üzerinden bağlantı verdikleri resmi sosyal medya hesaplardan Twitter ve Facebook'u kapsamaktadır. Araştırmanın ikinci yöntemi ise yarı yapılandırıımış mülakattır. Bu yöntemde, İzmir Büyükşehir Belediyesi başkan adayı Aziz Kocaoğlu'nun seçim kampansayını yürüten KeelBilled ajans başkanı Selim Kacar ile yarı yapılandırılmış mülakat gerçekleştirilmiştir.

\subsection{Araștırmanın Örneklemi}

Araştırmanın ilk aşamasında, Ak Parti, CHP ve MHP'nin 30 Mart 2014 Yerel Seçimleri İstanbul, Ankara ve İzmir Büyükşehir Belediye Başkan adayları, ikinci aşamada ise 10 Ağustos 2014 Cumhurbaşkanlığı Seçimleri'nde aday olan Recep Tayyip Erdoğan, Ekmeleddin İhsanoğlu ve Selehattin Demirtaş amaçı örneklem yöntemine göre seçilmiştir (Erdoğan, 2007: 176). Seçilen siyasi adayların, resmi web sayfaları üzerinden bağlantı verdikleri resmi Facebook ve Twitter hesapları araştırmaya dahil edilmiştir. Bu yöntem Baxter ve Marcella'nın İskoç partilerinin ve adaylarının sosyal medya profillerine yönelik olarak gerçekleştirdikleri araştırmanın uyarlamasıdır (Baxter ve Marcella, 2010). Birleşik Krallık Parlemento seçimleri sürecinde İskoç Parti ve Adayların faaliyet gösterdikleri sosyal medya hesaplarının içeriğini analiz etmiş, aday ve partilerin hangi sosyal medya ortamlarında resmi hesaplarının bulunduğunu ve adayların bu ortamlar aracılığıyla seçmenleri ile nasıl iletişim kurduklarını saptamaya çalışmışlardır (Baxter ve Marcella, 2012).

Araşıırma kapsamına alınan, 30 Mart 2014 Yerel Seçimlerine katılan adaylar ve 10 Ağustos 2014 Cumhurbaşkanlığı Seçimlerine katılan adayların listesi aşağıdaki gibidir.

Tablo 1. 30 Mart 2014 Yerel Seçimleri ve 10 Ağustos 2014 Cumhurbașkanliğına Katılan Adaylar, Partileri ve Sosyal Medya Hesapları

\begin{tabular}{|c|c|c|c|c|}
\hline \multicolumn{5}{|c|}{30 Mart 2014 Yerel Seçimlerine Katılan Adaylar, Partileri ve Sosyal Medya Hesapları } \\
\hline Aday & Parti & il & Twittrt & Facebook \\
\hline Kadir Topbaș & Ak Parti & İstanbul & Var & Var \\
\hline Mustafa Sarıg̈l & CHP & İstanbul & Var & Var \\
\hline Rasim Acar & MHP & İstanbul & Var & Var \\
\hline İbrahim Melih Gökçek & Ak Parti & Ankara & - & Var \\
\hline Mansur Yavaș & CHP & Ankara & Var & Var \\
\hline Mevlüt Karakaya & MHP & Ankara & Var & Var \\
\hline Binali Yıldırım & Ak Parti & İzmir & - & - \\
\hline Aziz Kocaoğlu & CHP & İzmir & Var & - \\
\hline Murat Tașer & MHP & İzmir & Var & Var \\
\hline \multicolumn{5}{|c|}{10 Ağustos 2014 Cumhurbașkanlığı Seçimlerine Katılan Adaylar } \\
\hline Ekmeleddin İhsanoğlu & - & - & Var & - \\
\hline Selahattin Demirtaș & - & - & Var & - \\
\hline Recep Tayyip Erdoğan & - & - & - & - \\
\hline
\end{tabular}

Araştırma kapsamına dahil edilen söz konusu adayların sosyal medya platformlarında sahip oldukları resmi Facebook ve Twitter hesaplarına içerik analizi uygulanarak çözümlenmeye çalışıımıştır. Bu bağlamda, Türkiye'deki siyasi adayların siyasal iletişim çalışmalarında sosyal 
medyanın yeri ve adayların, sosyal medya platformları üzerinden kurdukları iletişimin Grunig ve Hunt'un dört halkla ilişkiler modelinden hangisiyle örtüştüğü ve biçimsel olarak paylaşımların içerikleri belirlenmeye çalışılmıştır.

\subsection{Araștırmanın Sınırlılıkları}

Araştırmanın ilk aşaması 30 Mart 2014 Yerel Seçimleri'nde, üç büyükşehir belediyesi ve bu şehirlerin dokuz büyükşehir belediye başkan adaylarının Facebook ve Twitter hesaplarının 28 Şubat ve 30 Mart 2014 tarihleri arasında incelenmesi ile sınırıdır. Araştırmanın ikinci aşaması ise 10 Ağustos 2014 Cumhurbaşkanlığı Seçimleri'ne aday olan üç adayın Facebook ve Twitter hesaplarının 10 Temmuz - 10 Ağustos 2014 tarihleri arasında incelenmesi ile sınırıdır. Ayrıca söz konusu adayların seçim kampanyalarını yürüten uzmanlardan sadece birisine ulaşılarak mülakat yapılabilmiştir.

\subsection{Araștırma Soruları}

Siyasi adaylar sosyal medya ortamları üzerinden seçmen kitle ile iletişim kurmak adına kendi adlarına hesap oluşturmakta ve bu hesaplar üzerinden çeşitli paylaşımlarda bulunmaktadırlar. Sosyal medya bir siyasi kuruma veya siyasi aktöre seçmen kitle ile sanal ortamda biraraya gelme olanağı sunmaktadır (Okmeydan, 2013: 77). Bu açıdan bakıldığında sosyal medya siyasal aktörler açısından interaktif birer halkla ilişkiler aracı olarak öne çıkmaktadır. Ancak bu noktada adayın sosyal medyayı ne şekilde kullandığı ve seçmen kitle ile nasıl iletişim kurduğu önemlidir. Kişi ya da kurumu hiçbir zaman ve mekan sınırlaması olmaksızın biraraya getiren ve çift yönlü interaktif iletişim ortamına imkan veren sosyal medya, Türk siyasi adayları tarafından etkin birer halkla ilişkiler aracı olarak kullanılabilmekte midir? Bu bağlamda araştırmanın iki sorusu bulunmaktadır:

Araştırma sorusu 1: Adayların sosyal medya ortamları üzerinden hedef kitleleri ile kurdukları iletişim Grunig ve Hunt'ın çift yönlü halkla ilişkiler modellerindenhangisiyle örtüşmektedir?

Araştırma sorusu 2: Adaylar sosyal medya ortamlarındaki hesaplarından biçimsel olarak ne tür paylaşımlarda bulunmaktadır?

Söz konusu sorular; siyasi adayların sosyal medya üzerinden yürüttükleri halkla ilişkiler faaliyetlerinde sosyal medyayı ne denli etkin kullanabildiklerini saptamak amacıyla bu süreçte gerçekleştirdikleri çabaların modern halkla ilişkiler modelleri ile örtüşüp örtüşmediğini ve bu ortamlar üzerinden ne denli uygun biçimsel içerik paylaşabildiklerini ortaya koymayı amaçlamaktadır.

\subsection{Bulgular}

Araştırmanın 30 Mart 2014 Yerel Seçimleri ve 10 Ağustos 2014 Cumhurbaşkanlığı Seçimleri dönemi olmak üzere iki aşamadan oluşmasına ve iki seçim arasındaki zaman farkına rağmen benzer bulgular ortaya koyması dikkat çekicidir. Bu bağlamda yerel seçim döneminden, Cumhurbaşkanlığı seçim dönemine kadar geçen sürede adayların sosyal medya kullanım pratiklerinde bir gelişme ve değişme olmadığı gözlemlenmiş̧ir.

\subsection{1. İstanbul Büyükșehir Belediyesi Bașkan Adayları}

30 Mart 2014 Yerel Seçimleri'nde İstanbul Büyükşehir Belediyesi için Ak Parti'den mevcut Belediye Başkanı Kadir Topbaş, Cumhuriyet Halk Partisi'nden Mustafa Sarıgül ve Milliyetçi Hareket Partisi'nden Rasim Acar aday olmuşlardır. Adayların; 28 Şubat - 30 Mart tarihleri arasında Facebook ve Twitter hesaplarındaki aktiviteler aşağıdaki tablolarda yer almaktadır. 
Tablo 2. Kadir Topbaș Sosyal Medya Hesap Hareketleri

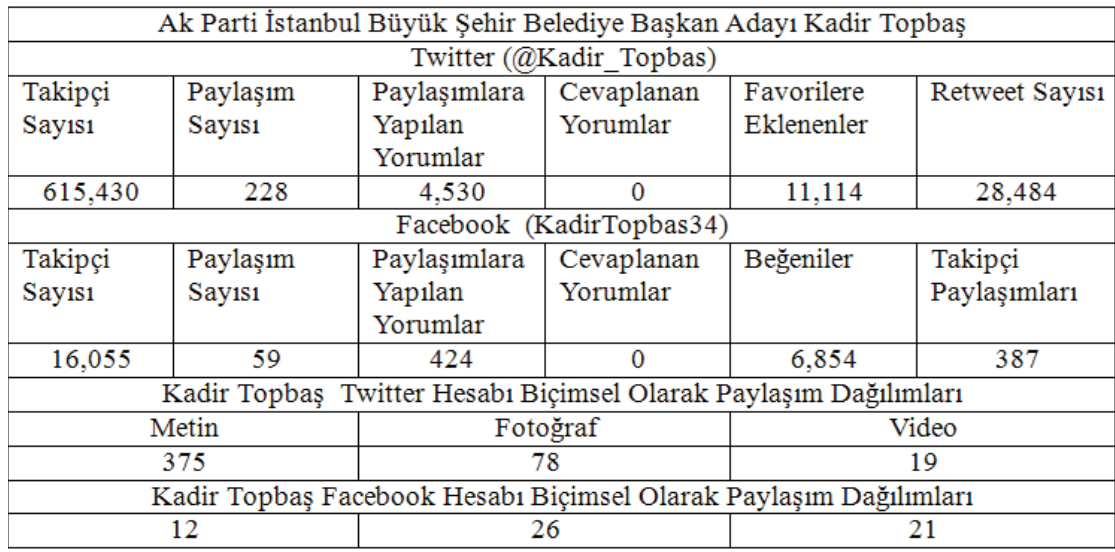

Kadir Topbaş'ın Twitter hesabının Facebook hesabına göre çok daha yoğun olarak kullanıldığı görülmektedir. 20 Mart tarihinde Twitter'a mahkeme kararı ile erişimin engellenmesinin ardından Topbaş'ın bu ortamda yaptığı paylaşımlar son bulmuştur. Ancak söz konusu iki hesapta da takipçiler tarafından paylaşımlara yapılan yorumlar cevapsız bırakılmıştır. Böylece kaynaktan alıcıya ve alıcıdan kaynağa doğru hareket eden iletişim bu noktada son bulmuştur. Böylece mesaj, kaynaktan alıcıya ve tekrar alıcıdan kaynağa doğru gitmekte ve iletişim son bulmaktadır. Bu durum Grunig ve Hunt'un çift yönlü asimetrik modeli ile örtüşmektedir. Ayrıca Topbaş'ın Twitter hesabından çoğunlukla metin paylaşıldığı, Facebook hesabından ise çoğunlukla fotoğraf ve video gibi görsellerin paylaşıldığı görülmektedir.

Tablo 3. Mustafa Sarıgül Sosyal Medya Hesap Hareketleri

\begin{tabular}{|c|c|c|c|c|c|}
\hline Takipci & Paylasım & Paylassımlara & Cevaplanan & Favorilere & Retweet Say1s1 \\
\hline Say1s1 & & $\begin{array}{l}\text { Yapilan } \\
\text { Yorumlar }\end{array}$ & Yorumlar & Eklenenler & \\
\hline 338,600 & 416 & 13,447 & 0 & 16.324 & 63.337 \\
\hline \multicolumn{6}{|c|}{ Facebook (mustafasarigul) } \\
\hline Takipçi & Paylașım & Paylașımlara & Cevaplanan & Beğeniler & Takipçi \\
\hline Say1s1 & & $\begin{array}{l}\text { Yapilan } \\
\text { Yorumlar }\end{array}$ & Yorumlar & & Paylașimları \\
\hline 352,339 & 35 & 12,384 & 0 & 295,747 & 27,856 \\
\hline \multicolumn{6}{|c|}{ Mustafa Sarıgül Twitter Hesabı Biçimsel Olarak Paylașım Dağılımları } \\
\hline \multicolumn{2}{|c|}{ Metin } & \multicolumn{2}{|c|}{ Fotoğraf } & \multicolumn{2}{|c|}{ Video } \\
\hline \multicolumn{2}{|c|}{316} & \multicolumn{2}{|c|}{81} & \multicolumn{2}{|c|}{19} \\
\hline \multicolumn{6}{|c|}{ Mustafa Sarı̈ül Facebook Hesabı Biçimsel Olarak Paylaşım Dağılımları } \\
\hline \multicolumn{2}{|c|}{2} & \multicolumn{2}{|c|}{7} & \multicolumn{2}{|c|}{26} \\
\hline
\end{tabular}

Mustafa Sarıgül örneğinde de Twitter hesabının Facebook hesabına oranla çok daha yoğun olarak kullanıldığı görülmektedir. Ayrıca Sarıgül, Twitter'den gerçekleştirdiği paylaşımların 211'ini 20 Mart 2014'de Twitter'a erişimin engellenmesinin ardından gerçekleştirmiştir. Ancak Sarıgül'ün iki sosyal medya hesabında da etkileşim oranları son derece yüksek olmasına karşın takipçiler tarafından paylaşımlara yapılan yorumlar cevapsız bırakılmıştır. Böylece mesaj, kaynaktan alıcıya ve tekrar alıcıdan kaynağa doğru gitmekte ve iletişim son bulmaktadır. Bu durum Grunig ve Hunt'ın çift yönlü asimetrik modeli ile örtüşmektedir. Ayrıca Mustafa Sarıgül'ün Twitter hesabında 
çoğunlukla metin paylaşımı yapııırken, Facebook hesabında paylaşımların büyük çoğunluğunu fotoğraf ve video gibi görsel öğelerin oluşturduğu görülmektedir.

Tablo 4. Rasim AcarSosyal Medya Hesap Hareketleri

\begin{tabular}{|c|c|c|c|c|c|}
\hline \multicolumn{6}{|c|}{ MHP İstanbul Büyük Șehir Belediye Bașkan Adayı Rasim Acar } \\
\hline \multicolumn{6}{|c|}{ Twitter (@rasimacar) } \\
\hline $\begin{array}{l}\text { Takipçi } \\
\text { Sayıs1 }\end{array}$ & Paylaşım & $\begin{array}{l}\text { Paylaşımlara } \\
\text { Yapılan } \\
\text { Yorumlar }\end{array}$ & $\begin{array}{l}\text { Cevaplanan } \\
\text { Yorumlar }\end{array}$ & $\begin{array}{l}\text { Favorilere } \\
\text { Eklenenler }\end{array}$ & Retweet Say1s1 \\
\hline 30,280 & 119 & 586 & 0 & 841 & 7,191 \\
\hline \multicolumn{6}{|c|}{ Facebook (rasimacarmhp) } \\
\hline $\begin{array}{l}\text { Takipçi } \\
\text { Sayıs1 }\end{array}$ & Paylaşım & $\begin{array}{l}\text { Paylașımlara } \\
\text { Yapılan } \\
\text { Yorumlar }\end{array}$ & $\begin{array}{l}\text { Cevaplanan } \\
\text { Yorumlar }\end{array}$ & Beğeniler & $\begin{array}{l}\text { Takipçi } \\
\text { Paylaşımları }\end{array}$ \\
\hline 5,634 & 57 & 132 & 0 & 4,854 & 993 \\
\hline \multicolumn{6}{|c|}{ Rasim Acar Twitter Hesabı Biçimsel Olarak Paylașım Dağılımları } \\
\hline \multicolumn{2}{|c|}{ Metin } & \multicolumn{2}{|c|}{ Fotoğraf } & \multicolumn{2}{|c|}{ Video } \\
\hline \multicolumn{2}{|r|}{61} & \multicolumn{2}{|c|}{37} & \multicolumn{2}{|c|}{21} \\
\hline \multicolumn{6}{|c|}{ Rasim Acar Facebook Hesabı Biçimsel Olarak Paylașım Dağılımları } \\
\hline \multicolumn{4}{|c|}{34} & \multicolumn{2}{|c|}{17} \\
\hline
\end{tabular}

Milliyetçi Hareket Partisi İstanbul Büyükşehir Belediye Başkan adayı Rasim Acar da, Twitter hesabını Facebook hesabına göre daha aktif kullanmaktadır. Rasim Acar Twitter'da gerçekleştirdiği paylaşımların 55'ini 20 Mart 2014'de Twitter'a erişimin engellenmesinin ardından gerçekleştirmiştir. Rasim Acar örneğinde de her iki sosyal medya hesabında da etkileşim oranlarının oldukça yüksek olmasına karşın takipçilerin paylaşımlara yaptıkları yorumlar cevaplanmamıştır. Böylece mesaj, kaynaktan alıcıya ve tekrar alıcıdan kaynağa doğru gitmekte ve iletişim son bulmaktadır. Bu durum Grunig ve Hunt'ın çift yönlü asimetrik modeli ile örtüşmektedir. Ayrıca, Rasim Acar'ın Twitter hesabında daha çok metin, Facebook hesabında ise çoğunlukla fotoğraf ve video gibi görsel öğelerin paylaşımının yapıldığı görülmektedir.

\subsubsection{Ankara Büyük Șehir Belediyesi Bașkan Adayları}

30 Mart 2014 Yerel Seçimleri'nde Ankara Büyükşehir Belediyesi için Ak Parti'den mevcut Ankara Büyükşehir Belediye Başkanı İbrahim Melih Gökçek, Cumhuriyet Halk Partisi'nden Mansur Yavaş, Milliyetçi Hareket Partisi'nden ise Mevlüt Karakaya aday olmuşlardır. Adayların; 28 Şubat - 30 Mart 2014 tarihleri arasında Facebook ve Twitter hesaplarındaki aktiviteler aşağıdaki tablolarda yer almaktadır.

Tablo 5. Ibrahim Melih Gökçek Sosyal Medya Hesap Hareketleri

\begin{tabular}{|c|c|c|c|c|c|}
\hline \multicolumn{6}{|c|}{ AK Parti Ankara Büyük Șehir Belediye Bașkan A } \\
\hline \multicolumn{6}{|c|}{ Twitter (@06melihgokcek) } \\
\hline $\begin{array}{l}\text { Takipçi } \\
\text { Sayı1s1 }\end{array}$ & Paylaşım & $\begin{array}{l}\text { Paylaşımlara } \\
\text { Yapılan } \\
\text { Yorumlar }\end{array}$ & $\begin{array}{l}\text { Cevaplanan } \\
\text { Yorumlar }\end{array}$ & $\begin{array}{l}\text { Favorilere } \\
\text { Eklenenler }\end{array}$ & Retweet Say1s1 \\
\hline $1,483,939$ & 386 & 7,720 & 0 & 21,118 & 74,403 \\
\hline \multicolumn{6}{|c|}{ Facebook (-) } \\
\hline $\begin{array}{l}\text { Takipçi } \\
\text { Sayıs1 }\end{array}$ & Paylaşım & $\begin{array}{l}\text { Paylaşımlara } \\
\text { Yapilan } \\
\text { Yorumlar }\end{array}$ & $\begin{array}{l}\text { Cevaplanan } \\
\text { Yorumlar }\end{array}$ & Beğeniler & $\begin{array}{l}\text { Takipçi } \\
\text { Paylaşımları }\end{array}$ \\
\hline- & - & - & - & - & - \\
\hline \multicolumn{6}{|c|}{ İbrahim Melih Gökçek Twitter Hesabı Biçimsel Olarak Paylaşım Dağılımları } \\
\hline \multicolumn{2}{|c|}{ Metin } & \multicolumn{2}{|c|}{ Fotoğraf } & \multicolumn{2}{|c|}{ Video } \\
\hline \multicolumn{2}{|c|}{375} & \multicolumn{2}{|c|}{11} & \multicolumn{2}{|c|}{-} \\
\hline \multicolumn{6}{|c|}{ İbrahim Melih Gökçek Facebook Hesabı Biçimsel Olarak Paylașım Dağılımları } \\
\hline & - & & & & \\
\hline
\end{tabular}


İbrahim Melih Gökçek incelenen sosyal medya platformlarından sadece Twitter'de resmi hesaba sahiptir. Gökçek'in Twitter hesabında yaptığı paylaşımlar 20 Mart 2014'de Twitter'e erişimin engellenmesi ile son bulmuştur. İbrahim Melih Gökçek'e atılan bazı Tweetlere (Twitter mesajları) cevap verildiği görülmektedir. Ancak İbrahim Melih Gökçek'in gönderilerine takipçileri tarafından yapılan yorumlar bu örnekte de karşııısız bırakılmışıı. Böylece mesaj kaynaktan alıcıya ve tekrar alıcıdan kaynağa ulaşmakta ancak iletişim bu noktada son bulmaktadır. Bu durum Grunig ve Hunt'ın çift yönlü asimetrik modeli ile örtüşmektedir. Ayrıca İbrahim Melih Gökçek'in Twitter hesabından daha çok metin mesajları paylaşıldığı gözlemlenmiştir.

Tablo 6. Mansur YavașSosyal Medya Hesap Hareketleri

\begin{tabular}{|c|c|c|c|c|c|}
\hline \multicolumn{6}{|c|}{ CHP Ankara Büyük Șehir Belediye Başkan Adayı Mansur Yavaș } \\
\hline \multicolumn{6}{|c|}{ Twitter(@mansuryavas06) } \\
\hline $\begin{array}{l}\text { Takipçi } \\
\text { Sayı1s1 }\end{array}$ & Paylaşım & $\begin{array}{l}\text { Paylașımlara } \\
\text { Yapılan } \\
\text { Yorumlar }\end{array}$ & $\begin{array}{l}\text { Cevaplanan } \\
\text { Yorumlar }\end{array}$ & $\begin{array}{l}\text { Favorilere } \\
\text { Eklenenler }\end{array}$ & Retweet Say1s1 \\
\hline 133,386 & 846 & 7,720 & 0 & 8,245 & 35,556 \\
\hline \multicolumn{6}{|c|}{ Facebook (-) } \\
\hline $\begin{array}{l}\text { Takipçi } \\
\text { Sayı1s1 }\end{array}$ & Paylaşım & $\begin{array}{l}\text { Paylașımlara } \\
\text { Yapılan } \\
\text { Yorumlar }\end{array}$ & $\begin{array}{l}\text { Cevaplanan } \\
\text { Yorumlar }\end{array}$ & Beğeniler & $\begin{array}{l}\text { Takipçi } \\
\text { Paylaşımları }\end{array}$ \\
\hline 25,682 & 55 & 2,753 & 0 & 54,602 & 3,753 \\
\hline \multicolumn{6}{|c|}{ Mansur Yavaș Twitter Hesabı Biçimsel Olarak Paylașım Dağılımları } \\
\hline \multicolumn{2}{|c|}{ Metin } & \multicolumn{2}{|c|}{ Fotoğraf } & \multicolumn{2}{|c|}{ Video } \\
\hline \multicolumn{2}{|c|}{738} & \multicolumn{2}{|c|}{76} & \multicolumn{2}{|c|}{32} \\
\hline \multicolumn{6}{|c|}{ Mansur Yavaş Facebook Hesabı Biçimsel Olarak Paylaşım Dağılımları } \\
\hline \multicolumn{2}{|c|}{10} & \multicolumn{2}{|c|}{34} & \multicolumn{2}{|c|}{11} \\
\hline
\end{tabular}

Cumhuriyet Halk Partisi Ankara Büyükşehir Belediye Başkanı Adayı Mansur Yavaş, Twitter’i daha yoğun kullanmaktadır. Ayrıca Mansur Yavaş'ın Twitter'da yaptığı yaplayşımların 381'i Twitter'a erişimin engellendiği 20 Mart ve sonrasında gerçekleşmiştir. Yavaş Twitter hesabında kendisine gönderilen birkaç Tweet'e cevap vermiştir ancak hesap takipçileri tarafından paylaşımlara yapılan yorumların cevapsız bırakıldığı görülmüştür. Böylece mesaj, kaynaktan alıcıya ve tekrar alıcıdan kaynağa doğru gitmekte ve iletişim son bulmaktadır. Bu durum Grunig ve Hunt'ın çift yönlü asimetrik modeli ile örtüşmektedir. Ayrıca Mansur Yavaş'ın Twitter hesabından büyük çoğunlukla metin paylaşımında, Facebook hesabından ise çoğunlukla fotoğraf ve video gibi içeriklerin paylaşıldığı görülmüştür.

Tablo 7. Mevlüt Karakaya Sosyal Medya Hesap Hareketleri

\begin{tabular}{|c|c|c|c|c|c|}
\hline \multicolumn{6}{|c|}{ MHP Ankara Büyük Șehir Belediye Bașkan Adayı Mevlüt Karakaya } \\
\hline \multicolumn{6}{|c|}{ Twitter(@karakayamevlut) } \\
\hline $\begin{array}{l}\text { Takipçi } \\
\text { Sayıs1 }\end{array}$ & Paylaşım & $\begin{array}{l}\text { Paylașımlara } \\
\text { Yapilan } \\
\text { Yorumlar }\end{array}$ & $\begin{array}{l}\text { Cevaplanan } \\
\text { Yorumlar }\end{array}$ & $\begin{array}{l}\text { Favorilere } \\
\text { Eklenenler }\end{array}$ & Retweet Say1s1 \\
\hline 24,409 & 72 & 432 & 0 & 641 & 4,683 \\
\hline \multicolumn{6}{|c|}{ Facebook (AnkaraMevlutKarakaya) } \\
\hline $\begin{array}{l}\text { Takipçi } \\
\text { Sayıs1 }\end{array}$ & Paylaşım & $\begin{array}{l}\text { Paylaşımlara } \\
\text { Yapilan } \\
\text { Yorumlar }\end{array}$ & $\begin{array}{l}\text { Cevaplanan } \\
\text { Yorumlar }\end{array}$ & Beğeniler & $\begin{array}{l}\text { Takipçi } \\
\text { Paylaşımları }\end{array}$ \\
\hline 66,301 & 104 & 2,753 & 0 & 54,602 & 3,753 \\
\hline \multicolumn{6}{|c|}{ Mevlüt Karakaya Twitter Hesabı Biçimsel Olarak Paylașım Dağılımları } \\
\hline \multicolumn{2}{|c|}{ Metin } & \multicolumn{2}{|c|}{ Fotoğraf } & \multicolumn{2}{|c|}{ Video } \\
\hline \multirow{2}{*}{\multicolumn{2}{|c|}{$\frac{62}{\text { Mevlüt Karak }}$}} & \multicolumn{2}{|c|}{9} & \multicolumn{2}{|c|}{9} \\
\hline & & \multicolumn{4}{|c|}{ Mevlüt Karakaya Facebook Hesabı Biçimsel Olarak Paylașım Dağılımları } \\
\hline \multicolumn{2}{|c|}{23} & \multicolumn{2}{|c|}{51} & \multicolumn{2}{|c|}{30} \\
\hline
\end{tabular}


Mevlüt Karakaya örneğinde diğer adayların aksine Facebook hesabının daha aktif bir biçimde kullanıldığı ve bu hesabın daha çok takipçi sayısına sahip olduğu görülmüştür. Mevlüt Karakaya, Twitter'da yaptığı paylaşımların 18'ini Twitter'a erişimin engellendiği 20 Mart ve sonrasında gerçekleştirmiştir. Ancak Mevlüt Karakaya'nın her iki sosyal medya platformunda da paylaşımlara yapılan takipçi yorumları cevapsız bırakılmıştır. Böylece mesaj, kaynaktan alıcıya ve tekrar alıcıdan kaynağa doğru gitmekte ve iletişim son bulmaktadır. Bu durum Grunig ve Hunt'ın çift yönlü asimetrik modeli ile örtüşmektedir. Ayrıca Mevlüt Karakaya'nın da Twitter hesabından çoğunlukla metin, Facebook hesabından ise fotoğraf ve video paylaşımında bulunduğu görülmüştür.

\subsection{3. İzmir Büyükșehir Belediyesi Bașkan Adayları}

30 Mart 2014 Yerel Seçimleri'nde İzmir Büyükşehir Belediyesi başkan adaylığı için Ak Parti'den Binali Yıldııım, Cumhuriyet Halk Partisi'nden mevcut Belediye Başkanı Aziz Kocaoğlu ve Milliyetçi Hareket Partisi'nden Murat Taşer aday olmuşlardır. Ak Parti adayı Binali Yıldırım'ın söz konusu dönemde sosyal medya platformlarında birçok aktif fan hesabı bulunmasına karşın kendisinin hiçbir sosyal medya platformunda resmi hesabı olmamıştır. Binali Yıldırım dışındaki adayların 28 Şubat - 30 Mart tarihleri arasında Facebook ve Twitter hesaplarındaki aktiviteler aşağıdaki tablolarda yer almaktadır.

Tablo 8. Aziz KocaoğluSosyal Medya Hesap Hareketleri

\begin{tabular}{|c|c|c|c|c|c|}
\hline \multicolumn{6}{|c|}{ CHP İzmir Büyük Șehir Belediye Bașkan Adayı Aziz Kocaoğlu } \\
\hline \multicolumn{6}{|c|}{ Twitter (@bskazizkocaoglu) } \\
\hline $\begin{array}{l}\text { Takipçi } \\
\text { Sayıs1 }\end{array}$ & Paylaşım & $\begin{array}{l}\text { Paylașımlara } \\
\text { Yapilan } \\
\text { Yorumlar }\end{array}$ & $\begin{array}{l}\text { Cevaplanan } \\
\text { Yorumlar }\end{array}$ & $\begin{array}{l}\text { Favorilere } \\
\text { Eklenenler }\end{array}$ & Retweet Say1s1 \\
\hline 41,458 & 142 & 1,988 & 0 & 2,818 & 3,456 \\
\hline \multicolumn{6}{|c|}{ Facebook - } \\
\hline $\begin{array}{l}\text { Takipçi } \\
\text { Say1s1 }\end{array}$ & Paylașim & $\begin{array}{l}\text { Paylașımlara } \\
\text { Yapılan } \\
\text { Yorumlar }\end{array}$ & $\begin{array}{l}\text { Cevaplanan } \\
\text { Yorumlar }\end{array}$ & Beğeniler & $\begin{array}{l}\text { Takipçi } \\
\text { Paylașımları }\end{array}$ \\
\hline - & - & - & - & - & - \\
\hline \multicolumn{6}{|c|}{ Aziz Kocaoğlu Twitter Hesabı Biçimsel Olarak Paylașım Dağılımları } \\
\hline \multicolumn{2}{|c|}{ Metin } & \multicolumn{2}{|c|}{ Fotoğraf } & \multicolumn{2}{|c|}{ Video } \\
\hline \multicolumn{2}{|c|}{93} & \multicolumn{2}{|c|}{41} & \multicolumn{2}{|c|}{3} \\
\hline \multicolumn{6}{|c|}{ Aziz Kocaoğlu Facebook Hesabı Biçimsel Olarak Paylașım Dağılımları } \\
\hline \multicolumn{2}{|r|}{-} & \multicolumn{2}{|c|}{-} & \multicolumn{2}{|c|}{-} \\
\hline
\end{tabular}

Cumhuriyet Halk Partisi, İzmir Büyükşehir Belediye Başkan adayı ve mevcut Başkanı Aziz Kocaoğlu'nun incelenen sosyal medya platformlarından sadece Twitter'de resmi hesabı bulunmaktadır. Aziz Kocaoğlu Twitter hesabından yaptığı paylaşımların 42'sini 20 Mart 2014'de Twitter'a erişimin engellenmesinin ardından gerçekleştirmiştir. Söz konusu hesapta etkileşim oranlarının yüksek olmasına karşın paylaşımlara yapılan takipçi yorumları karşılıksız bırakılmıştır. Böylece mesaj, kaynaktan alıcıya ve tekrar alıcıdan kaynağa doğru gitmekte ve iletişim son bulmaktadır. Bu durum Grunig ve Hunt'ın çift yönlü asimetrik modeli ile örtüşmektedir. Ayrıca Aziz Kocaoğlu'nun Twitter hesabında çoğunlukla metin paylaşımında bulunulduğu görülmüştür.

Aziz Kocaoğlu'nun sosyal medya üzerinden seçim kampanyasını yöneten KeelBilled Ajans Başkanı Selim Kacar ile yapılan mülakatta, Kacar; adayın kendi resmi Twitter hesabı üzerinden hedef kitle ile interaktif iletişim kurulmadığını belirtti. Aziz Kocaoğlunun Twitter'daki paylaşımlarına takipçileri tarafından yapılan yorumların cevapsız bırakıldığını belirten Kacar, partililer tarafından kurulan gönüllü hesaplarda sayfa takipçileri ile sayfa yönetimi arasındazaman zaman diyalog ortamının oluştuğunu belirtti. Gönüllüler tarafından açılan söz konusu hesapların direk parti 
ve adayın adını taşımadığını belirten Selim Kacar, bu hesaplar üzerinden sayfa takipçilerine adayın, belediye başkanlığı döneminde gerçekleştirdiği icraatların duyurulduğunu söyledi. Ajans başkanının belirttiği bu hususlar, aslında resmi olmayan gönüllü hesaplar da çift yönlü iletişimin varlığı söz konusu olsa da,bu ortamların duyurum amacıyla kullanıldığını ortaya koymaktadır.

Tablo 9. Murat Tașer Sosyal Medya Hesap Hareketleri

\begin{tabular}{|c|c|c|c|c|c|}
\hline \multicolumn{6}{|c|}{ MHP İzmir Büyük Sehir Belediye Baskan Aday1 Murat Taser } \\
\hline \multicolumn{6}{|c|}{ Twitter (@murattaserr) } \\
\hline $\begin{array}{l}\text { Takipçi } \\
\text { Sayıs1 }\end{array}$ & Paylaşım & $\begin{array}{l}\text { Paylaşımlara } \\
\text { Yapılan } \\
\text { Yorumlar }\end{array}$ & $\begin{array}{l}\text { Cevaplanan } \\
\text { Yorumlar }\end{array}$ & $\begin{array}{l}\text { Favorilere } \\
\text { Eklenenler }\end{array}$ & Retweet Say1s1 \\
\hline 1,182 & 408 & 1,024 & 0 & 600 & 888 \\
\hline \multicolumn{6}{|c|}{ Facebook (murattaserr) } \\
\hline $\begin{array}{l}\text { Takipçi } \\
\text { Sayıs1 }\end{array}$ & Paylaşım & $\begin{array}{l}\text { Paylașımlara } \\
\text { Yapılan } \\
\text { Yorumlar }\end{array}$ & $\begin{array}{l}\text { Cevaplanan } \\
\text { Yorumlar }\end{array}$ & Beğeniler & \begin{tabular}{|l|} 
Takipçi \\
Paylaşımları
\end{tabular} \\
\hline 3,073 & 101 & 640 & 0 & 1,800 & 116 \\
\hline \multicolumn{6}{|c|}{ Murat Tașer Twitter Hesabı Biçimsel Olarak Paylașım Dağılımları } \\
\hline \multicolumn{2}{|c|}{ Metin } & \multicolumn{2}{|c|}{ Fotoğraf } & \multicolumn{2}{|c|}{ Video } \\
\hline & 203 & & & & 38 \\
\hline \multicolumn{6}{|c|}{ Murat Tașer Facebook Hesabı Biçimsel Olarak Paylașım Dağılımları } \\
\hline \multicolumn{2}{|r|}{22} & \multicolumn{2}{|c|}{73} & \multicolumn{2}{|c|}{6} \\
\hline
\end{tabular}

Milliyetçi Hareket Partisi, İzmir Büyükşehir Belediye Başkan Adayı Murat Taşer'in Twitter hesabının daha aktif olduğu görülmektedir. Murat Taşer'in Twitter'de yaptığı paylaşımların 40'ı 20 Mart 2014'de Twitter'e erişimin engellenmesinin ardından gerçekleşmiştir. Ancak Murat Taşer'in iki sosyal medya hesabında da paylaşımlara yapılan takipçi yorumları cevapsız bırakılmışıır. Böylece mesaj, kaynaktan alıcıya ve tekrar alıcıdan kaynağa doğru gitmekte ve iletişim son bulmaktadır. Bu durum Grunig ve Hunt'ın çift yönlü asimetrik modeli ile örtüşmektedir. Murat Taşer'in Twitter hesabından çoğunlukla metin, Facebook hesabından ise çoğunlukla fotoğraf ve video paylaşımında bulunduğu görülmüştür.

\subsubsection{Ağustos 2014 Cumhurbașkanlığı Seçimleri}

10 Ağustos 2014 Seçimleri Türkiye'de Cumhurbaşkanı'nın ilk kez halk tarafından seçilmesi açısından önemlidir. Bu süreçte Cumhurbaşkanlığı'na Recep Tayyip Erdoğan, Ekmeleddin İhsanoğlu ve Selehattin Demirtaş olmak üzere üç aday talip olmuştur. Bu süreçte Başbakanlık görevini yürüten Recep Tayyip Erdoğan adına partililer ve hayranları tarafından birçok sosyal medya hesabı yürütülmesine karşın kendisinin bu süreçte hiçbir resmi sosyal medya hesabı olmamıştır. Ekmeleddin ìnsanoğlu ve Selehattin Demirtaş'ın ise 10 Temmuz - 10 Ağustos tarihleri arasında Facebook ve Twitter hesaplarındaki aktiviteler aşağıdaki tablolarda yer almaktadır. 
Tablo 10. Cumhurbașkanı Adayı Ekmeleddin IhsanoğluSosyal Medya Hesap Hareketleri

\begin{tabular}{|c|c|c|c|c|c|}
\hline \multicolumn{6}{|c|}{ Ekmeleddin İhsanoğlu } \\
\hline \multicolumn{6}{|c|}{ Twitter (@profdrihsanoglu) } \\
\hline $\begin{array}{l}\text { Takipçi } \\
\text { Say1s1 }\end{array}$ & Paylaşım & $\begin{array}{l}\text { Paylaşımlara } \\
\text { Yapılan } \\
\text { Yorumlar }\end{array}$ & $\begin{array}{l}\text { Cevaplanan } \\
\text { Yorumlar }\end{array}$ & $\begin{array}{l}\text { Favorilere } \\
\text { Eklenenler }\end{array}$ & Retweet Say1s1 \\
\hline 297,988 & 272 & 4,352 & 0 & 623,114 & 662,067 \\
\hline \multicolumn{6}{|c|}{ Facebook ( ekmelihsanoğlu ) } \\
\hline $\begin{array}{l}\text { Takipçi } \\
\text { Say1s1 }\end{array}$ & Paylaşım & $\begin{array}{l}\text { Paylașımlara } \\
\text { Yapılan } \\
\text { Yorumlar }\end{array}$ & $\begin{array}{l}\text { Cevaplanan } \\
\text { Yorumlar }\end{array}$ & Beğeniler & $\begin{array}{l}\text { Takipçi } \\
\text { Paylaşımları }\end{array}$ \\
\hline 391,906 & 84 & 42,479 & 0 & 756,283 & 186,024 \\
\hline \multicolumn{6}{|c|}{ Ekmeleddin İhsanoğlu Twitter Hesabı Biçimsel Olarak Paylaşım Dağılımları } \\
\hline \multicolumn{2}{|c|}{ Metin } & \multicolumn{2}{|c|}{ Fotoğraf } & \multicolumn{2}{|c|}{ Video } \\
\hline \multicolumn{2}{|c|}{189} & \multicolumn{2}{|c|}{63} & \multicolumn{2}{|c|}{20} \\
\hline \multicolumn{6}{|c|}{ Ekmeleddin İhsanoğlu Facebook Hesabı Biçimsel Olarak Paylașım Dağılımları } \\
\hline \multicolumn{2}{|c|}{0} & \multicolumn{2}{|c|}{52} & \multicolumn{2}{|c|}{32} \\
\hline
\end{tabular}

Ekmeleddin İhsanoğlu'nun Twitter hesabının Facebook hesabına oranla daha az takipçiye sahip olmasına karşın daha aktif bir biçimde kullanıldığı görülmüştür. Ancak İhsanoğlu'nun her iki sosyal medya hesabında da oldukça yüksek etkileşim oranlarının ortaya çıkmasına karşın hesap takipçileri tarafından paylaşımlara yapılan yorumlar karşılıksız bırakılmıştır. Böylece mesaj, kaynaktan alıcıya ve tekrar alıcıdan kaynağa doğru gitmekte ve iletişim son bulmaktadır. Bu durum Grunig ve Hunt'ın çift yönlü asimetrik modeli ile örtüşmektedir. İhsanoğlu'nun Twitter hesaplarındaki paylaşımın çoğunlukla metin paylaşımı olduğu, Facebook hesabındaki paylaşımlarının ise tamamının fotoğraf ve video gibi görsel öğelerden oluştuğu görülmüştür.

Tablo 11. Cumhurbașkanı Adayı Selehattin DemirtașSosyal Medya Hesap Hareketleri

\begin{tabular}{|c|c|c|c|c|c|}
\hline \multicolumn{6}{|c|}{ Selahattin Demirtaş } \\
\hline \multicolumn{6}{|c|}{ Twitter (@hdpdemirtas) } \\
\hline $\begin{array}{l}\text { Takipçi } \\
\text { Say1s1 }\end{array}$ & Paylaşım & $\begin{array}{l}\text { Paylaşımlara } \\
\text { Yapilan } \\
\text { Yorumlar }\end{array}$ & $\begin{array}{l}\text { Cevaplanan } \\
\text { Yorumlar }\end{array}$ & $\begin{array}{l}\text { Favorilere } \\
\text { Eklenenler }\end{array}$ & Retweet Say1s1 \\
\hline 297,988 & 28 & 860 & 0 & 47,505 & 75,678 \\
\hline \multicolumn{6}{|c|}{ Facebook (HDPdemirtas ) } \\
\hline $\begin{array}{l}\text { Takipçi } \\
\text { Sayısı }\end{array}$ & Paylaşım & $\begin{array}{l}\text { Paylaşımlara } \\
\text { Yapilan } \\
\text { Yorumlar }\end{array}$ & $\begin{array}{l}\text { Cevaplanan } \\
\text { Yorumlar }\end{array}$ & Beğeniler & $\begin{array}{l}\text { Takipçi } \\
\text { Paylaşımları }\end{array}$ \\
\hline $1,317,685$ & 0 & 0 & 0 & 0 & 0 \\
\hline \multicolumn{6}{|c|}{ Selehattin Demirtaș Twitter Hesabı Biçimsel Olarak Paylașım Dağılımları } \\
\hline \multicolumn{2}{|c|}{ Metin } & \multicolumn{2}{|c|}{ Fotoğraf } & \multicolumn{2}{|c|}{ Video } \\
\hline \multicolumn{2}{|c|}{26} & \multicolumn{2}{|c|}{1} & \multicolumn{2}{|c|}{1} \\
\hline \multicolumn{6}{|c|}{ Selehattin Demirtaș Facebook Hesabı Biçimsel Olarak Paylașım Dağılımları } \\
\hline \multicolumn{2}{|r|}{-} & \multicolumn{2}{|c|}{-} & \multicolumn{2}{|c|}{-} \\
\hline
\end{tabular}

Selahattin Demirtaş'ın incelenen tarihler arasında Facebook hesabında hiçbir paylaşımda bulunmadığı görülmüştür. Twitter hesabı da yine söz konusu tarihler etkin bir biçimde kullanılmamıştır. Bu durum Demirtaş'ın seçim dönemlerinde sosyal medya yerine geleneksel siyasal iletişim faaliyetlerini tercih ettiği şeklinde yorumlanabilir. Selahattin Demirtaş 10 Temmuz - 10 Ağustos 2014 tarihleri arasında Twitter hesabından sadece 28 paylaşımda bulunmasına karşın büyük oranda etkileşim ortaya çıkmıştır. Ancak takipçiler tarafından Selahattin Demirtaş'ın paylaşımlarına yapılan yorumlar cevapsız bırakılmışıı. Böylece mesaj, kaynaktan alıcıya ve 
tekrar alıcıdan kaynağa doğru gitmekte ve iletişim son bulmaktadır. Bu durum Grunig ve Hunt'ın çift yönlü asimetrik modeli ile örtüşmektedir. Ayrıca Selahattin Demirtaş'ın Twitter hesabındaki paylaşımların metin paylaşımından ibaret olduğu görülmüştür.

Araştırma kapsamında incelenen tüm adayların incelenen resmi sosyal medya hesapları üzerinden hedef kitleleri ile diyalog kuramadıkları ve sosyal medyanın yapısı gereği ortaya çıkan iletişimin Grunig ve Hunt'ın çift yönlü asimetrik modeli ile örtüştüğü görülmektedir. Araştırma kapsamındaki adayların sosyal medya hesapları üzerinden yaptıkları paylaşımlar biçimsel olarak incelendiğinde ise Twitter'in daha çok metin mesajları paylaşımında Facebook'un ise fotoğraf ve video gibi görsel içerikli materyallerin paylaşımında kullanıldığı görülmüştür.

\section{Sonuc}

Araştırma kapsamında 30 Mart 2014 Yerel Seçimleri döneminde belediye başkan adaylarının Facebook ve Twitter hesaplarına seçmenler tarafından yoğun ilgi gösterildiği ve etkileşim oranlarının yüksek olduğu görülmüştür. Ancak tüm bunlara karşın adaylar bu ortamlar üzerinden takipçileri ile diyalog kurmaktan kaçınmışlardır. İncelenen hesaplarda adayların yaptıkları paylaşımların takipçileri tarafından büyük ilgi gördüğü ve bu paylaşımlara çok sayıda yorum yazıldığı saptanmıştır. Buna karşın adayların profillerine takipçileri tarafından yazılan yorumlar karşııksız bırakılmışıı. Bu bağlamda ortaya çıkan iletişim sosyal medyanın yapısı gereği Grunig ve Hunt'ın çift yönlü asimetrik halkla ilişkiler modeli ile örtüşmektedir. Araştırma bulgularında yer alan bir diğer önemli husus ise Türkiye'de mahkeme kararı ile 20 Mart 2014 tarihinde Twitter'a erişimin engellenmesidir. Bu süreçte Ak Parti'li adaylar 20 Mart sonrasında Twitter hesaplarını kullanmazken diğer adaylar yasağı aşarak Twitter'dan paylaşımda bulunmaya devam etmişlerdir. Ayrıca adayların Twitter hesapları üzerinden çoğunlukla metin mesajları paylaştıkları, Facebook hesapları üzerinden ise fotoğraf ve video gibi görsel öğeleri paylaştıkları görülmüştür.

Araştırmanın ikinci aşamasını oluşturan 10 Ağustos 2014 Cumhurbaşkanlığı Seçimleri döneminde adaylardan Recep Tayyip Erdoğan'ın kendi adına parti teşkilatları ve hayranları tarafından işletilen güncel birçok sosyal medya hesabı bulunmasına karşın kendisinin resmi sosyal medya hesabı bulunmamaktadır. Diğer iki adayın resmi Facebook ve Twitter hesapları incelendiğinde ise yerel seçimler sürecindeki belediye başkanı adaylarının sosyal medya kullanımı ile benzer bulgular ortaya çıkmıştır. Adayların yapmış oldukları paylaşımlara hesap takipçileri tarafından büyük ilgi gösterilmesi ve etkileşim oranlarının yüksek olmasına karşın takipçilerin paylaşımlara yaptığı yorumlar cevapsız bırakılmıştır. Bu açıdan bakıldığında ortaya çıkan iletişim yine sosyal medyanın yapısı gereği Grunig ve Hunt'ın dört halkla ilişkiler modelinden çift yönlü asimetrik model ile örtüşmektedir. Ayrıca seçim döneminde Selahattin Demirtaş'ın Facebook hesabından hiç paylaşımda bulunmadığı görülmüştür bu durum Selahattin Demirtaş'ın seçim çalışmalarında geleneksel yöntemlere daha çok önem verdiği şeklinde yorumlanabilir. İhsanoğlu ise Twitter hesabını Facebook hesabına göre çok daha aktif kullandığı ve Twitter'dan metin, Facebook hesabından ise fotoğraf ve video gibi görsel öğeleri paylaşmayı tercih ettiği görülmüştür.

Hiçbir zaman ve mekan sınırlaması olmadan kaynak ve alıcıyı biraraya getirme ve anında geri bildirim edinme olanağı sağlayan sosyal medya platformlarının siyasal iletişim çalışmalarında dünyada önemi giderek artmaktadır. Genç, dinamik ve iletişim teknolojilerine yoğun ilgi gösteren bir nüfusa sahip olan ülkemizde benzeri bir araştırma birkaç yıl sonra tekrar edildiğinde çok farklı sonuçların ortaya çıkabilmesi mümkündür. 


\section{Kaynakça}

Açıkel, Emre ve Çelikol, Mehmet (2012). Dijitoloji, Pazarlama ve Satış. İstanbul: MediaCat.

Akar, Erkan (2011). Sosyal Medya Pazarlaması, Sosyal Web’te Pazarlama Stratejileri. Ankara: Efil.

Alemdar, Yeniçeri, Mine ve Köker, Nahit, Erdem (2011). "Siyasi Partilerin 2007 - 2011 Türkiye Genel Seçimlerinde Web Sitesi Kullanımı ve Karşılaştırmalı Analizi”. Erciyes Üniversitesi, Sosyal Bilimler Enstitüsü Dergisi.2(31): 225-254.

Alikılıç A., Özlem (2011). Halkla İlişkiler 2,0, Sosyal Medyada Yeni Paydaşlar, Yeni Teknikler. Ankara: Efil. Aziz, Aysel. (2011). Siyasal İletişim. İstanbul: Nobel.

Barut, Basri ve Altundağ, Sinan (2005). "Globalleşen Dünyada Bir Siyasal İkna Unsuru Olarak Vaatler (3 Kasım 2002 Türkiye Milletvekili Genel Seçimleri İle 2 Kasım 2004 ABD Başkanlık Seçimleri Karşılaştırmalı Örneğiyle)". Selçuk Üniversitesi İletişim Fakültesi Akademik Dergisi.1(4): 80-90.

Baxter, Graeme and Marcella, Rita (2012). "DoesScotland 'like' This? Social Media Use by Political Parties and Candidates in Scotland during the 2010 UK General ElectionCampaign". Libri.2(62): 109-124.

Bayraktutan, Günseli; Binark, Mutlu, Çomu, Tuğrul, Doğu; Burak, İslamoğlu; Aydemir, Gözde; Telli, Aslı. (2012). "Sosyal Medyada 2011 Genel Seçimleri: Nitel-Nicel Arayüzey İncelemesi". Selçuk Üniversitesi İletişim Fakültesi Akademik Dergisi.3 (7): 5-29.

Erdoğan, İrfan (2007). Pozitivist Metodoloji. Bilimsel Araştırma Tasarımı, İstatiksel Yöntemler, Analiz ve Yorum. Ankara: Erk.

Grunig, James, Grunning, Larissa, Sriramesh, Krishnamurthy (1995). "Models of Public Relations in an International Setting". Journal of Public Relations Research. 3(7): 163-186.

Grunig, James ve White, Jon. (2005). Temel Kuram, Derleyen Grunig, James. Halkla İlişkiler ve İletişim Yöntemlerinde Mükemmellik. İstanbul: Rota.

Hanson, Gary, Haridakis, M., Paul, Cunningham, Audrey, Sharma, Rekha (2010). "The 2008 Presidential Campaign: Political Cynicism in the Age of Facebook, MySpace, and YouTube". Mass Communication and Society. 5 (13): 584-607.

Kahraman, Murat (2013). Sosyal Medya 101 2.0, Pazarlama için Sosyal Medyaya Giriş, İstanbul, MediaCat.

Karaçor, Süleyman (2009). Yeni Illetişim Teknolojileri, Siyasal Katılım, Demokrasi, Yönetim ve Ekonomi, Cilt.16, Sayı 2.

Kılıçaslan, Emine (2008). Siyasal İletişimde İdeolojik Dil. Yayınlanmamış Yüksek Lisans Tezi. Edirne: T.Ü. SBE.

Okay, Ayla ve Okay, Aydemir (2007). Halkla İlişkiler, Kavram Strateji ve Uygulamaları. Yayınları. İstanbul: Der.

Okmeydan, Cudi Kaan (2013). Türkiye'deki Siyasi Partilerin Halkla İlişkiler Çalışmalarında Sosyal Medya Kullanımı, Yayınlanmış Yüksek Lisans Tezi. İzmir: Yaşar Üniversitesi Sosyal Bilimler Enstitüsü Iletişim Anabilim Dalı.

Oktay, Mahmut (2002). Politikada Halkla İlişkiler. İstanbul: Derin.

Sarı, Hasan (2010). Siyasal İletişimde Yeni İletişim Teknolojilerinin Kullanımı: 2009 Yerel Seçimlerinde Ak Parti'nin Çalışmaları. Yayınlanmamış Doktora Tezi. Ankara: G.Ü. SBE. 
Strömback, Jasper\&Kiousis, Spiro (2011). PoliticalPublicRelations, Principles and Applications. London: Routledge.

Tokgöz, Oya (2010). Seçimler Siyasal Reklamlar ve Siyasal İletişim. İstanbul: İmge

Toth, Elizabeth. (2008). The Future of Excellence in Public Relations and Communication Management: Challenges for the next generation edited. Londra: Lawrence Erlbaum.

Vural Akıncı, Beril ve Bat, Mikail (2009). "Siyasal Seçim Kampanyalarında Yeni İletişim Teknolojileri ve Blog Kullanımı: 2008 Amerika Başkanlık Seçimlerine Yönelik Karşılaştırmalı Bir Analiz”. Journal of Yaşar University. 4(16): 2745-2778.

Wilcox, Dennis ve Cameron, Glen (2011).PublicRelationsStrategiesandTactics. New York: Pearson.

Yolçu, Neslihan. (2011). 12 Eylül Anayasa Referandumunda Siyasal Partilerin İnternet Kullanımı ve Kampanya Söylemleri, TheAcademicJournal Of Information Technologies, Spring, I.2 